\title{
Property Rights Violations as a Structural Driver of Women's HIV Risks: A Qualitative Study in Nyanza and Western Provinces, Kenya
}

\author{
Shari L. Dworkin, \\ Social and Behavioral Sciences and Center for AIDS Prevention Studies, University of California \\ at San Francisco, 3333 California Street, LHTS \#455, San Francisco, CA 94118, USA \\ Shelly Grabe, \\ Department of Psychology, University of California at Santa Cruz, Santa Cruz, CA, USA \\ Tiffany Lu, \\ Department of Medicine, Massachusetts General Hospital, Boston, MA, USA \\ Abbey Hatcher, \\ Department of Obstetrics, Gynecology and Reproductive Sciences, Bixby Center for \\ Reproductive Health, University of California at San Francisco, San Francisco, CA, USA \\ Zachary Kwena, \\ Center for Microbiology Research, Kenya Medical Research Institute (KEMRI), Kisumu, Kenya \\ Elizabeth Bukusi, and \\ Center for Microbiology Research, Kenya Medical Research Institute (KEMRI), Kisumu, Kenya \\ Esther Mwaura-Muiru \\ GROOTS-Kenya, PO Box 10320-GPO, Nairobi, Kenya
}

Shari L. Dworkin: shari.dworkin@ucsf.edu

\section{Abstract}

\begin{abstract}
While access to and control over assets can minimize women's HIV risk, little is known about the processes through which property rights violations increase the sexual transmission of HIV. The current study focused on two rural areas in Nyanza and Western Province, Kenya where HIV prevalence was high (23.8-33\%) and property rights violations were common. The current work drew on in-depth interview data collected from 50 individuals involved in the development and implementation of a community-led land and property rights program. The program was designed to respond to property rights violations, prevent disinheritance and asset stripping, and reduce HIV risk among women. In our findings, we detailed the social and economic mechanisms through which a loss of property rights was perceived to influence primary and secondary prevention of HIV. These included: loss of income, loss of livelihood and shelter, and migration to slums, markets, or beaches where the exchange of sex for food, money, shelter, clothing, or other goods was common. We also examined the perceived influence of cultural practices, such as wife inheritance, on HIV risk. In the conclusions, we made recommendations for future research in the science-base focused on the development of property ownership as a structural HIV prevention and treatment intervention.
\end{abstract}

(C) Springer Science+Business Media, LLC 2012

Correspondence to: Shari L. Dworkin, shari.dworkin@ucsf.edu. 


\section{Keywords}

HIV prevention and treatment; Women; Sexual risk; Property ownership; Structural interventions; Kenya

\section{Introduction}

HIV/AIDS prevention researchers have increasingly recognized the need to move from individual and small-group interventions towards an emphasis on the large-scale structural determinants of disease (Adimora \& Auerbach, 2010; Auerbach, 2009; Gupta, Parkhurst, Ogden, Aggleton, \& Mahal, 2008; Sumartojo, 2000). This is particularly the case in SubSaharan Africa, where research has demonstrated the role of economic disempowerment and gender inequality in the spread of HIV/AIDS and where women constitute more than $60 \%$ of HIV cases (Kim et al., 2007; Kim \& Watts, 2005; Pronyk et al., 2005, 2006, 2008; UNAIDS, 2010). Innovative structural approaches are said to be urgently needed within the next generation of HIV/AIDS prevention interventions (Adimora \& Auerbach, 2010; Coates \& Szekeres, 2004; Gupta et al., 2008; Parker, Easton, \& Klein, 2000; Pronyk et al., 2005, 2006, 2008).

In the past decade, HIV prevention programs aimed at economic disempowerment and gender inequalities have grown in prevalence, with several recent interventions concentrating on income generation activities, such as microfinance. Although these programs have shown some promise, both in terms of the impact on women's empowerment measures and on health and sexual risk indicators (Dunbar et al., 2010; Hashemi \& Schuler, 1996; Kim et al., 2007; Pronyk et al., 2006; Schuler \& Hashemi, 1994; Sherman, German, Cheng, Marks, \& Bailey-Kloche, 2006), recent findings have demonstrated that focusing on income alone as an HIV prevention strategy has major limitations. In particular, empirical investigations have demonstrated that women often do not have control over the additional household income derived in such programs and, therefore, it is questionable whether income-generation fundamentally alters gendered power relations that relate to women's HIV risks (Dupas \& Robinson, 2009; Garikapati, 2008; Goetz \& Sen Gupta, 1996; Prina, 2011). In other words, effectively targeting poverty may provide for women's short-term material needs, but may not alter their broader societal status or gendered power in their relationships (Kabeer, 2001; Mayoux, 1998). As such, scholars have argued that expanding women's control over property, a harder asset, may be one way to better address power relations between women and men (Agarwal, 1994; Razavi, 2008) and reshape the risk of HIV and violence in the process (Dworkin, Kambou, Sutherland \& Kapoor, 2009; ICRW, 2007a).

The HIV/AIDS epidemic intersects with a lack of land ownership. Research has suggested that inequities in resource distribution (income, property) contribute to power imbalances that exacerbate women's low status and adversely influence their health and safety (Deshmukh-Ranadive, 2005; Glick \& Fiske, 1999; Jenkins, 2000; Wingood \& DiClemente, 2000). This dynamic is particularly visible in East Africa (Englert \& Daley, 2008), where women are frequently stripped of their property and other assets or evicted from their homes when a husband dies of HIV/AIDS or other causes (FIDA, 2009; Huairou Commission, 2009; Izumi, 2007; Mendenhall et al., 2007; UNAIDS, 2010; Walsh, 2005). In particular, because women's property rights violations in Sub-Saharan African can worsen their poverty, it is theorized that this amplifies women's HIV risks through a loss of shelter and assets, a loss of livelihood strategies, and/or migration to markets or slum areas where women exchange sex for money in order to survive (Henrysson \& Joireman, 2009; ICRW, 2004, 2007a; Walker, 2002; Yngstrom, 2002). Researchers theorize that these trends occur 
because of numerous factors, including: gender inequality, government/community officials who value customary processes over legal documentation, a lack of rights knowledge, a lack of formal documents to confer land ownership, and a lack of enforcement of formal laws (FIDA, 2009; ICRW, 2004, 2007b). However, few published research studies have empirically examined the linkages between a lack of property rights and primary and secondary transmission of HIV risk and very few have been carried out in the Kenyan context (for an exception, see Aliber \& Walker, 2006).

Simultaneously, a small body of literature is emerging that demonstrates links between property ownership and women's likelihood of experiencing physical and sexual violence in West Bengal, Nepal, Nicaragua, and South Africa (Grabe, 2010; ICRW, 2007a; Izumi, 2007; Panda \& Agarwal, 2005; Pandey, 2010). Given that violence increases HIV risk among women (Dunkle et al., 2006: Jewkes, Levin, \& Penn-Kakana, 2003; Jewkes, Sikweyiya, Morrell, \& Dunkle, 2009), it is crucial to further understand the role of property in reducing both violence and HIV among women.

Taking a critical view of how structural inequities perpetuate gender-based HIV risks requires an examination of the social and economic mechanisms through which property rights might lead to HIV risk and treatment outcomes. Recognition of the interdependence between property rights and the HIV epidemic has led to a number of non-governmental (NGO) and community-based organizations (CBOs) to focus on this link in their HIV/AIDS care programs (ICRW, 2007b). The development of such programs has outpaced research examining their structure, content, and effects. Program developers and implementers who are involved in integrated property rights and HIV programs have seen and handled hundreds of disinheritance and eviction cases and have useful knowledge that can help to characterize the distinctive links between property rights and HIV risks. In addition, understanding why these programs emerged and how these programs work on the ground can help to elucidate the mechanisms through which property ownership may work to reduce HIV risks. Such knowledge is critical for the development of future structural interventions that sit at the juncture of land and property and the HIV epidemic.

The current work draws on in-depth interview data collected from 50 individuals involved in the development and implementation of a community-led land and property rights program. The program was designed to respond to property rights violations, prevent disinheritance and asset stripping, and reduce HIV risk among women. The present study focused on two rural areas in Kenya-Kakamega and Kendu Bay_in Nyanza and Western Province, respectively, where HIV prevalence is high (23.8-33\%) and property rights violations are common (Republic of Kenya, 2008a, 2008b). HIV rates in the districts of Kakamega and Kendu Bay are significantly higher than the national seroprevalence rate in Kenya, which is $7.4 \%$, and are even higher than the average $(15 \%)$ rates found in the worst affected province (Nyanza) (Kenya Ministry of Health, 2008; UNAIDS, 2010). This article draws on qualitative evidence collected to examine how women's property rights violations are perceived to influence primary and secondary HIV transmission in rural, southwestern Kenya.

\section{Method}

\section{Participants}

We recruited 50 individuals who were closely involved with one community-led land and property rights program in Kenya (described below). Twenty of the individuals were responsible for developing the model for this program (referred to as developers throughout); this was the full population of individuals identified as being involved in its development. The other 30 individuals were randomly selected from a comprehensive list of 
those responsible for implementing the program (this included members who were trained paralegals, Chiefs, Assistant Chiefs, and Land Tribunal Officials) (referred to as implementers throughout). We sampled 30 program implementers based on Morse's (1994) recommendation for sample size minimums in qualitative research that are needed to attain adequate saturation and redundancy of themes. Demographic information about developers and implementers in this sample are shown in Table 1.

\section{Procedure}

The data for the current study were collected through an academic-community based collaboration between the University of California at San Francisco (UCSF), the Kenya Medical Research Institute (KEMRI), and GROOTS-Kenya. GROOTS-Kenya is a national network of community-based organizations and women's self-help groups founded after the 4th UN Conference on Women in Beijing as a response to the inadequate visibility of grassroots women in anti-poverty, leadership, and health endeavors. GROOTS-Kenya is one of the few organizations that has developed and implemented a flagship program to respond to the massive number of property rights violations in the Kenyan context, named the "Community Land and Property Watch Dog" (CWDG) model.

CWDG is designed to secure women's property ownership and access and to reduce the spread and impact of HIV and AIDS. The model is operationalized as Watch Dog Groups on the local level and is comprised of groups of women and men, traditional leaders, trained paralegals, and government stakeholders. The CWDG serves as a community-led mechanism that monitors women's disinheritance locally and draws on multiple strategies to prevent a loss of property and resolve disinheritance issues. The strategies include training community members to be paralegals who can then assist with property rights violations, mediating land disputes with family members, land tribunal stakeholders, and other government officials, referring unresolved cases to formal adjudication mechanisms, and educating community members (both women and men) about protecting women's land tenure and property rights. Given the widespread occurrence of property rights violations and the lack of available services in rural communities, WDGs have been established in more than 30 locations in Kenya, are concentrated in Nyanza Province, Western Province, and Central Province, and altogether have managed more than 200 cases of women's property rights violations.

\section{Measures}

To minimize bias, in-depth interviews were carried out by interviewers who were hired through human resources at KEMRI, all of whom were external to GROOTS-Kenya but who were familiar with the communities in which we worked. These interviewers were trained in qualitative research methods and Human Subjects Review principles by the lead author to administer an interview guide. The interview domains focused on what happened to women when their husbands passed away, the reasons for property rights violations, the perceived links between property loss and HIV transmission, and the barriers and facilitators to securing women's access to, use, and control of land. The protocol was approved by the Human Subjects Review Boards at KEMRI and UCSF. In accordance with IRB rules in Kenya, participants were offered 500 Kenyan shillings (equivalent to US \$6) for their transportation only. Interviews lasted between 1.25 and $2.25 \mathrm{~h}$ and were conducted in the local languages. Following completion, interviews were first transcribed into the local language and then into English.

To begin the coding process, two researchers extracted excerpts of the transcribed interviews relating to all of the domains of interest mentioned above. To establish a codebook, six interviews were randomly selected and independently evaluated using an open coding 
process employed during the initial phase of coding often deployed in qualitative research (Lofland \& Lofland, 1995; Strauss \& Corbin, 1994). From this initial process of broad category generation, an additional four randomly selected interviews were coded. After a second round of coding, coders met to ensure full refinement of primary and secondary categories referred to as focused, intensive, or axial coding (Berg, 2001; Lofland \& Lofland, 1995; Strauss \& Corbin, 1994). Once the full range of categories was established, the remaining interviews were double coded independently by the first and fourth authors. Following independent coding of these transcripts, decision trails were noted and documented, and the overall concordance rate across coding categories was calculated to be $94 \%$ across the interviews. As coding categories were straight forward, discrepancies were not common. In nearly all cases, discrepancies were simple miscodes and did not involve substantive discussions. Once the coding was completed, we used analytical memos (Lofland \& Lofland, 1995) to note recurrent themes and to lift the more minor subcodes into a conceptual analysis. To facilitate the coding and analysis, we used Dedoose, a qualitative data analysis software program.

In the results that follow, we first examine the perceived need for the development of an integrated HIV and property rights program. To better understand the mechanisms through which a loss of property rights influences HIV transmission, we examined the process of disinheritance and the economic and social factors that were perceived to shape the primary and secondary prevention of HIV.

\section{Results}

\section{Emergence of a Property Rights Program: "She Would Disappear"}

Participants in our study made it clear that the need for a property rights program emerged out of the high HIV sero-prevalence context that existed across numerous rural Kenyan communities. Specifically, interviewees explained that GROOTS-Kenya was carrying out home-based care giving within HIV-affected households (to ensure that family members were eating well, living well, and adhering to their ARV medications). It was here that home-based care givers learned that women "would disappear" from the home suddenly. When home-based care givers investigated what happened to the missing women, this led to widespread understanding that women's property rights were being violated in these communities:

Kenya and Kakamega particularly where we live is an area really hit by HIV/AIDS. When we started providing home-based care, in the house that the person lives in, we would visit the person, link them to a comprehensive care clinic, and we start taking them through the steps of living positively, accepting their status, going to VCT (voluntary counseling and testing). Then along the way, when the husband dies, or if we enroll a widow... she would disappear. But, we knew that she was living there! And when we were following up...we would hear that she had been chased away by the in-laws or she has been denied to use land. So, this was the genesis behind the community land and property Watch Dog Group and the land issues in our community. It was actually part of our HIV/AIDS program. (Implementer, Female, age 42)

Nearly all of the interviewees expressed that property rights violations occurred in part because women were blamed for bringing HIV into the household and were subsequently thrown out of the household. For example, across sites it was explained that:

In our case, there is a lot of connection between HIV/AIDS and property rights.... When a family or couple is affected with HIV/AIDS, most of the time it is perceived that it is this woman who has bought HIV/AIDS in the family and what 
the families do is that they chase the woman away. When they are chasing her away, she is losing her property. (Developer, Female, age 28).

In many cases, the language used by the in-laws was that the woman was at fault for the death of their son (her husband). Because families often perceived that HIV meant a rapid death, they felt entitled to take over the property and send the woman back to her maternal home:

Especially in this community, when a man dies, they say it is the woman who brought the sickness. And the woman was stigmatized, the woman would be told "now we know you will die the next day." So whatever property was in that home, your brothers-in-law or mother-in-law or your father-in-law...they would take hold of that property and say the woman will not ever inherit it. The woman is told "you have to go to your home." (Implementer, Male, age 42)

Interviewees perceived that the practice of disinheritance increased the HIV prevalence across several communities, and that a program that protected women's right to own property was essential to lower the HIV prevalence. For example:

It was clear why we needed to halt issues of women's inheritance rights violations, besides being a violation against women is that we understood that the more we allow young widows to go and move to the shopping centers or to the slums, and those ones who got engaged with commercial sex work, it was a sure way of actually either helping them to get re-infected or really increasing the prevalence rates in our community. (Implementer, Woman, age 43)

At the same time that community health workers found that there was an epidemic of "missing women" in households affected by HIV/AIDS, they came to learn that women were not simply being cast out of the household (disinherited), but they were also having their belongings taken by in-laws (asset stripped). The process of asset stripping and property grabbing began soon after the husband died; this process (described below) revealed economic and social mechanisms that led to increased HIV risks.

\section{Perceived Links Between Property Rights Violations and HIV Risks: Property Stripping and Disinheritance Led to Economic and Social Vulnerabilities}

Nearly all of the interviewees expressed that women were particularly vulnerable to property rights violations during the time in which they were grieving the death of their husbandsmany of whom died of HIV, but some of whom died from other causes. Interviewees reported that the in-laws would seize the woman's belongings and begin a process of grabbing her property and pushing her out of her home during the woman's grieving process. In the words of an Assistant Chief:

Women are much more vulnerable to lose property. What can I say? When somebody dies, they are not interested in things like ID, like signing the forms, death certificate forms, they rely on their relatives, and those relatives are the ones who are taking their properties from them. You see, when the death occurs, the women only, they are much of the ones to cry. But when they are crying, the communities are taking their things. She will come to realize that my such and such a thing... is not there...my certificate is not there. (Developer, Male, age 47)

Several interviewees described that it was during the funeral planning when in-laws were acting quickly to take hold of women's belongings. As explained by one participant:

The Watch Dog group members are normally keen during the funeral process. Though the wife is here grieving with her children and they have sat them with some of the community members discussing how the funeral is going to be 
organized, somebody is looting her house...not community members looting her house, but just the family members....they are taking her pots and pans, taking away furniture, taking away clothes... so it does happen that they lose quite a bit of property. Most women are trained in the villages as seamstresses and they lose their sewing machine...so they can't even earn a living. Everything is gone, away. (Developer, Female, age 44)

Across the sample, it was noted that during disinheritance, most or all of a woman's assets and personal belongings were taken in addition to property, usually by in-laws:

When they are disinherited, they take everything. It is only the clothes she owns that are not taken...it is everything. Land, animals, cows, cars...the brothers-inlaw, mostly the in-laws. (Developer, Male, age 58)

Developers and implementers of this program have seen and/or assisted hundreds of women who are disinherited and hence they have a first-hand view of what happens to women in their communities. They explained that with no belongings left, no income, no source of livelihood, and nowhere to go, women left their homes, often with their children, and sought to begin life elsewhere. Hence, the combination of disinheritance and asset stripping produced major economic vulnerabilities for women. This, in turn, led to a process of migration where women searched for work and a place in which to live. These social and economic mechanisms were perceived by both developers and implementers to be the central factors through which HIV risk was produced, and were described as making HIV care and treatment much more difficult, if not impossible, for the HIV infected.

\section{Perceived Links Between Property Rights Violations and HIV Risks: Economic and Social Vulnerabilities Led to Resultant Migration}

A common theme mentioned by most interviewees underscored that when women were asset stripped of belongings, had their property taken, and are disinherited and cast away from their homes, this process stimulates migration to markets, beaches, or slum areas where many women either took on new sexual partners or exchanged sex for money, food, shelter, or clothing for her and/or her children. Most interviewees underscored that this happens to both HIV positive and HIV negative women. In the case of HIV negative women, nearly all interviewees suggested that women who were thrown out of their homes often acquire new partners to secure food, shelter, or clothing:

So, you see... a woman, the husband can even die because of an accident...because of those people who have an interest, they fight her, they chase her from that home. Then this woman, according to our culture, she has no right to go and get a piece of land from the ancestral home. Then she loses where to settle, she becomes displaced, she goes and rents a house in the market. While she's in the market, because of this poverty, she will start looking for her daily bread. While in that process, a man may come to seduce her, they will become sexual partners, then she'll be infected with HIV/AIDS. Just imagine, because of losing her property at this side, she goes and gets HIV/AIDS at that end. (Implementer, Female, age 45)

Within new relationships, many women exchanged sex for food, goods, or housing and this was noted by participants as placing women at risk of HIV acquisition:

Shelter is one of the basic things in human life. A woman will go and resolve to stay in town, and when you go to live in town, won't you pay for that house? When you are going to pay? Where will you get money? That might make you resort in to even doing somethings so that you can pay for this house and this will shorten your life and this is a major problem... (Implementer, Male, age 46) 
Town markets were one primary location where women migrated to after being disinherited. Migrating to the beaches near Lake Victoria was another common destination. At the beaches, there is a thriving sex-for-fish economy where women secured their source of fish to sell in the local market through sex with fisherman. Previous research on the sex-for-fish economy in Nyanza Province, referred to as the Jaboya system, is very limited, but there have been linkages made between the sex-for-fish trade, social and economic relations, and HIV risk surrounding the lake (Camlin, Kwena, \& Dworkin, 2012; Mojola, 2011). For example, our interviewees reported that:

When you are staying at the beaches and you don't have anything...you don't have a livelihood, anybody... any man who is around there becomes your man. So you see, these are the things they do...prostitution to survive. Even at the beaches... some of them stay at the beaches, even those widows who go there, before you are given fish... you must prostitute. I have been by the lake for many years where... that's what they do. You cannot trade without prostituting. You cannot trade fish without prostituting. That's what is happening down there. You see? (Implementer, Female, age 34)

Some interviewees did not refer to these actions explicitly as prostitution given that many of these exchanges were in the context of local sex-for-fish or goods ecologies and/or relationships. Many interviewees perceived that when women acquired multiple male partners, these relationships were formed, in part, to secure goods, food, housing, or school fees for children. This was perceived to increase the HIV prevalence in the community overall:

Mostly this is a problem brought about by men, because they are moving about with so many women, and you as the wife you are left back home, and the husband ends up bringing that disease to you at home. And here comes a problem again, the husband has gone, he has passed away, you are left with the kids, and your in-laws are chasing you away from the matrimonial home. So you are chased away, and most of the women end up hiring some rooms at the shopping center. And by doing so, so because the woman would like her kids to eat, what she will do, she will do prostitution and then the spread of HIV/AIDS will continue. (Developer, Male, age 35)

Some interviewees also suggested that children sometimes exchanged sex for food given women's and children's high degree of food insecurity and poverty once they were disinherited. For example:

Children are being affected because you know when the children are out there, and maybe they don't have food, like girls...they need to buy pads, they need to do what...they have to go about and look for money. And you know when they have sex they don't know they will be infected. (Developer, Female, age 46)

These two prominent themes indicated that there were economic and social mechanisms through which property rights violations increased HIV/AIDS risks for both women and men in the community at large. At the same time, several interviewees mentioned cultural practices such as wife inheritance that were also perceived to increase women's and men's HIV risks.

\section{Perceived Links Between Disinheritance and HIV Risks: Wife Inheritance, Sexual Cleansing, and Refusing Wife Inheritance}

Several interviewees perceived that HIV risk was heightened through the practice of wife inheritance whereby the brother of the decreased husband inherits the woman instead of casting her away from home. This practice was commonly perceived to assist the woman by 
retaining her in the family. However, this practice was also viewed as increasing HIV risks in the community because the deceased husband may have died of HIV and may have transmitted the virus to his wife, who can then transmit to her inheritor. Second, there was the practice of "sexual cleansing," which was described as sexual intimacy with an inheritor after the death of a husband; this intimacy was rarely described as protected sex. Third, some women refused to be inherited, and this refusal meant that the in-laws pushed women out of their homes even more forcefully, leaving her economically insecure and in need of migration to secure an income.

In terms of the perception of increased HIV risk in the community, participants described how inheritance by family members may lead to secondary transmission of HIV:

So in the Luhya community, they talk about things like wife inheritance, which was very, very popular. So they are like yes, you would go, and you would be assisted by being retained in the family by being inherited by the brothers, the brother of the deceased. But you see also that brought issues because now you are inheriting me, you are not really sure about my [HIV] status, and you are not sure about why my husband passed away, and this is also another avenue of spreading HIV.

(Developer, Female, age 42, brackets added)

Others explained that the brothers-in-law of the deceased husband sought to inherit the wife even if they knew that she was HIV positive:

I will explain to you well this saying that "a cow dies with grass in its mouth." A man, even if he accepts that the home to which he is going is where the owner died of HIV/AIDS... and this was his brother. He saw how he [the owner/his brother] used to have diarrhea, he saw how he coughed, and at time she is the one who would be sent to go and get medicine when his brother was down. But because this woman who has been left is beautiful and her body is good, he says that that was just a disease that the clan was using against them. He will go and he'll...he will marry the woman whose husband died, knowing very well that his brother died of HIV/AIDS, that is what "a cow dying with grass in its mouth" means. He will go and he knows there is death there, because the woman is nicely living. So that man was being sought after by the clan...that is why he died. So they say that even if it's what is going to happen, I am going. So someone like that you cannot tell them to stop. That is the "cow dying with grass in its mouth." He will go and he knows. (Implementer, Female, age 35)

Being inherited was viewed as something that should happen in the community even though this was perceived to increase HIV risks. Several interviewees underscored that if women resisted inheritance after the death of one's husband, this became a reason to forcefully push them out of their homes, and there were also perceived risks associated with retaining her in the family:

Like now, you see, there was this issue of inheritance. Where a widow must be inherited. So may be this widow has not been inherited. That is a reason for the inlaws to chase her away. So I would say to them this: if she is positive, and then you want your son to inherit, are you not seeing you are going to lose your son, the other son? I think there was a lack of awareness. There was a lack of awareness. (Developer, Female, age 55)

In addition to the common perception that HIV risk increased through economic and social mechanisms and cultural practices mentioned above, interviewees also discussed how disinheritance exacerbated the negative impact of the epidemic, making HIV care and treatment much more difficult. 


\section{Disinheritance and Disruption of Antiretroviral Care: Property Rights and Secondary Prevention of HIV}

Approximately half of the interviewees underscored that migration to markets, beaches, or slum areas was very disruptive in terms of clinical care for women who were HIV positive. This was because property rights violations and disinheritance interrupted women's ability to access clinical care or take antiretroviral medications and this impacted their ability to remain healthy:

So, whatever property was in that home, your brothers-in-law or your mother-inlaw or father-in-law, they would take hold of that property and say the woman will not even inherit...So she would be sent away...so most of the women went to the shops, and she cannot take her medications because she is sick, and has been sent away from the home. (Developer, Female, age 43)

Others participants agreed:

One of the key health issues affecting women in the rural areas is that most of the women who are disinherited are living with HIV/AIDS or they are poor women. If they are left to stay in their communities without being chased, they have access to health services and maybe they will go to a health dispensary and get ARVs. Secondly, she can use her land to earn income. Those living with HIV, their health is especially destabilized because they are chased away when they are not even prepared, so they will not tell their clinicians " "I have been chased away, give me a transfer form for me to take drugs elsewhere" and then the clinician would ask them to "go back to the other place" and "get a transfer form from the hospital in which you were" and that was really very difficult because these were poor women. But if women are helped to stay on their land, these are some of the things that will not arise. So many women defaulted on ARVs because of such kinds of things. (Developer, Female, age 28)

The above themes revealed that the disinheritance process led to major difficulties for women in terms of being able to access and maintain HIV care and treatment.

\section{Discussion}

Recent theoretical work has highlighted some of the potential economic and social pathways that link HIV and property rights violations (Dworkin et al., 2009; ICRW, 2004, 2007a; Kes, Jacobs, \& Nami, 2011; USAID, 2009) but further empirical research is clearly needed to elucidate these processes. There is ample reason to believe that inequitable access to land and property may shape the structural context through which imbalances in power are sustained, creating risk environments for women. Because customary norms and practices throughout most of the world recognize the male head of household as the main authority figure and principle owner of land assets, land ownership in "developing" countries reflects dominant roles and elevated status in society and households (Deere \& Leon, 2001; Palmer, 2008; Pena, Maiques, \& Castillo, 2008). It is well established that when culturally sanctioned gender roles foster power imbalances, women often have little control over their physical safety or sexual decisions (Connell, 1987; Gupta, 2001; Kalichman et al., 2005). Because access to and control over hard assets, such as land and property, can improve women's status in the communities in which they live and increase their household bargaining power (Aliber \& Walker, 2006; Izumi, 2007; Walsh, 2005), it is possible that programs which bolster women's land tenure may mitigate the harmful effects of HIV/AIDS and reduce HIV/AIDS risks (Dworkinetal., 2009; ICRW, 2004, 2007a; Kes et al., 2011).

There are very few works that empirically examine the processes through which property ownership may operate to reduce primary and secondary transmission or improve treatment 
and care outcomes. Through our in-depth qualitative research, we found that there appear to be economic and social processes through which secure property rights might decrease the HIV vulnerability of women. Some of these processes included: providing women with a secure place to live, serving as a site for economic activity and means of livelihood, reducing the exchange of sex for goods, food, money, or shelter, and reducing economic dependencies with male partners. With the help of property rights programs that work to respond to property rights violations, and prevent disinheritance and asset stripping (such as the CWDG model examined in this paper), land can also serve as women's collateral for credit for income-generating activities that can act as risk reduction mechanisms (Pronyk et al., 2005, 2008; Sherman et al., 2006). Such programs are important not only because they increase women's ability to secure their livelihood, but also because these shift the dynamics of land ownership. This is critical because women often do not have any collateral for loans because land is often registered only in the man's name as the head of the household.

Our research highlighted an important aspect of gender inequality within the era of HIV/ AIDS: blaming the woman for "bringing the disease" into the family. In the context of widespread antenatal HIV testing, a pregnant woman is often the first family member to test and may be blamed for bringing the virus into the family or may suffer from adverse consequences of status disclosure (Bond, Chase, \& Aggleton, 2002; Turan, Miller, Bukusi, Sande, \& Cohen, 2008). Women are less likely to test for HIV if they fear violence or discrimination by partners (Antelman et al., 2001; Kilewo et al., 2001; Medley, GarciaMoreno, McGill, \& Maman, 2004). For HIV-positive women, the threat of violence is also an important barrier to HIV status disclosure (Moore, Kalanzi, \& Amey, 2008) and enrollment into care and treatment (Hatcher et al., 2012) — both of which are considered essential steps to preventing further HIV transmission. Thus, the current study contributes to the literature by highlighting that a fear of violence and discrimination by extended family in the process of disinheritance may create additional pressures for women to avoid HIV testing, care, or treatment. Such a finding has implications for the structural prevention of primary and secondary transmission of HIV.

Our finding that many women migrated once they were disinherited and asset stripped parallels research elsewhere in sub-Saharan Africa that calls attention to the contribution of migration to exacerbating women's HIV/AIDS risks. These risks are posited to be due to the specific reasons for women's migration (e.g., violence, HIV, disinheritance), risks in the migratory process itself, and/or women's increased biological and social vulnerability to HIV risks at the point of destination (Camlin, Kwena, \& Dworkin, 2012; Camlin, Kwena, Dworkin, Cohen, \& Bukusi, 2012; Kes et al., 2011; UNAIDS, 2010). Hence, innovative programs such as CWDG that prevent a loss of property and assets may act as an important structural tool for HIV prevention. The CWDG model may prevent HIV by reducing disinheritance and therefore preventing migration to beaches, markets, or urban slum dwellings, where we learned that sex is frequently exchanged for food, money, goods, educational fees, or housing. Certainly, depending on the reasons as to why women migrate, some women may want to leave their home and not return. For those who do migrate, HIV prevention interventions and linkages to care at these destinations are needed for both widows and children. Yet, CWDG may provide an important model for reducing primary and secondary transmission by securing women's economic well-being and livelihoods and preventing out-migration at the community source while helping women to return to land and to their homes at their point of origin.

Consistent with the current HIV/AIDS literature, our own research also revealed that there were cultural practices such as widow inheritance (where a woman whose male partner has died is expected to have sex and/or a marry or have a long-term relationship with a male relative) that may further contribute to HIV/AIDS risks (Agot et al., 2010; ICRW, 2004; 
Izumi, 2007; Walsh, 2005). Here, programs that engage and build the capacity for village elders and community leaders to learn and apply rights-based knowledge may be particularly promising, particularly given the influence that such leaders have on shifting cultural patterns that are deemed to be harmful while also influencing outcomes associated with land ownership.

Our research revealed that improving women's ownership of property and assets may also expand their capacity to manage and lessen the risk of HIV acquisition and decrease behaviors that lead to secondary transmission. The economically and socially empowering aspects of property ownership may be particularly important in Kenya where our own and other research suggests that households affected by HIV/AIDS may be more likely to experience land disputes and threats to land tenure compared with other households (Aliber \& Walker, 2006; Seeley, Grellier, \& Barnett, 2004).

Much work remains to be done in the field of structural HIV prevention. There is a clear need for rigorous measurement that can characterize the empowerment-related processes (social and economic) that are associated with land access, use, and control—and to examine their individual and community-level impacts on HIV. Little research has evaluated men's responses to programs, such as the CWDG model, that seek improvements in women's property access to, use, and control over land. Given recent research that reveals that HIV programming that focuses on women's empowerment can be synergistic with or create tensions with the goals of gender equality and health programming, the involvement of men in these efforts should not be overlooked and should be carefully considered (Dworkin, Dunbar, Krishnan, Hatcher, \& Sawires, 2011). Finally, little research has characterized the strategies that community programmers deploy to successfully protect women from losing property, assets, or being disinherited. This knowledge will be critical for the development of future research that seeks to examine the impact of property ownership as a structural HIV prevention or treatment intervention. Our own research in these areas is in process and forthcoming.

There were several limitations to this study. First, interviewees were part of a program that focused on land rights and HIV issues; hence, their own personal investment in the program likely contributed to bias. To reduce this bias, we hired interviewers external to the program and asked a very large number of probes to check answers for consistency. Second, while our sample was relatively large for a qualitative study, it was by no means fully representative of all staff in this particular program. Third, the sample was also not generalizable to all regions in Kenya that have a high seroprevalence rate or to all programs that focus on work at the intersection of property and HIV prevention/mitigation. Still, within this understudied area, we have offered preliminary qualitative results about some of the economic, social, and cultural mechanisms that may be operating to link property rights violations and HIV risks, as well as elucidating some of the ways that property rights abuses can contribute to the disruption of clinical care. Suggested areas for future research include a quantitative examination of whether widows experience higher rates of HIV and violence because of a loss of land ownership relative to their landowning counterparts. In addition, testing the impact of an integrated property rights and HIV prevention program to see whether it is more efficacious than our best HIV prevention alone is a fertile question to explore.

Indeed, the need for action at the program and policy level at the intersection of property and HIV and AIDS has become increasingly clear. Three of the Millennium Development Goals intersect at the juncture of this topic-Goal \#1 is to reduce poverty, goal \#3 is to promote gender equality and empower women, and Goal \#6 is to combat HIV and AIDS. At the 53rd Commission on the Status of Women in New York in 2009, the UN special envoy for AIDS 
in Africa, Elizabeth Mataka, was quoted as saying that "lack of equal rights for women to inheritance and property rights excludes women from accessing resources that would help reduce their vulnerability to HIV and cope with the consequences of the epidemic" (UNAIDS, 2009). Additionally, Kenyans have voted recently on a new Constitution and a National Land Policy (Kenya has not had a clearly defined National Land Policy since independence), both of which could create a vibrant new policy environment in which to improve upon women's property rights and HIV/AIDS risks. Now is the time to translate these innovative programs and national policy shifts into targeted research agendas within the HIV/AIDS prevention science base, and to disseminate the findings of such research.

\section{Acknowledgments}

This research was supported by a grant from the National Institutes of Health, University of California, San Francisco Gladstone Institute of Virology \& Immunology, Center for AIDS Research, P30-AI027763. The authors are grateful to the anonymous reviewers and the Editor for their helpful comments. The authors are grateful to the Director of the Kenya Medical Research Institute (KE-MRI) and the Director of the Center for Microbiology Research at KEMRI for their guidance on and support of this work.

\section{References}

Adimora AA, Auerbach JD. Structural interventions for HIV prevention in the United States. Journal of Acquired Immune Deficiency Syndrome. 2010; 55:S132-S135.

Agarwal, B. Field of one's own: Property rights in South Asia. Cambridge: Cambridge University Press; 1994.

Agot KE, Vander Stoep A, Tracy M, Obare BA, Bukusi EA, Ndinya-Achola JO, et al. Widow inheritance and HIV prevalence in Bondo District, Kenya: Baseline results from a prospective cohort study. PLoS ONE. 2010; 5:e14028. [PubMed: 21103347]

Aliber M, Walker C. The impact of HIV/AIDS on land rights: Perspectives from Kenya. World Development. 2006; 34:704-727.

Antelman G, Smith Fawzi MC, Kaaya S, Mbwambo J, Msamanga GI, Hunter DJ, et al. Predictors of HIV-1 serostatus disclosure: A prospective study among HIV-infected pregnant women in Dar es Salaam, Tanzania. AIDS. 2001; 15:1865-1874. [PubMed: 11579250]

Auerbach J. Transforming social structures and environments to help in HIV prevention. Health Affairs. 2009; 28:1655-1665. [PubMed: 19887406]

Berg, B. Qualitative research methods for the social sciences. Boston: Allyn \& Bacon; 2001.

Bond V, Chase E, Aggleton P. Stigma, HIV/AIDS and prevention of mother-to-child transmission in Zambia. Evaluation and Program Planning. 2002; 25:347-356.

Camlin, C.; Kwena, Z.; Dworkin, SL. Jaboya vs. Jakambi: Status, negotiation and HIV risks among female migrants in the "sex for fish" trade in Nyanza Province, Kenya. 2012. Manuscript submitted for publication

Camlin, C.; Kwena, Z.; Dworkin, SL.; Cohen, C.; Bukusi, E. Typologies of migration and mobility and contexts of HIV risk among women in Nyanza Province, Kenya. 2012. Manuscript submitted for publication

Coates TJ, Szekeres G. A plan for the next generation of HIV prevention research: Seven key policy investigative challenges. American Psychologist. 2004; 59:747-757. [PubMed: 15554841]

Connell, RW. Gender and power: Society, the person, and sexual politics. Palo Alto, CA: Stanford University Press; 1987.

Deere CD, Leon M. Who owns the land? Gender and land-titling programmes in Latin America. Journal of Agrarian Change. 2001; 1:440-467.

Deshmukh-Ranadive, J. Measuring empowerment: A gender analysis of household and family dynamics. New Dehli, India: Centre for Women's Development Studies; 2005.

Dunbar MS, Maternowska MC, Kang MJ, Laver SM, Mudekunye-Mahaka I, Padian NS. Findings from SHAZ!: A feasibility study of a microcredit and life-skills HIV prevention intervention to 
reduce risk among adolescent female orphans in Zimbabwe. Journal of Prevention and Intervention in the Community. 2010; 38:147-161. [PubMed: 20391061]

Dunkle KL, Jewkes RK, Nduna M, Levin J, Jama N, Khuzwayo N, Koss MP, Duvvury N. Perpetration of partner violence and HIV risk behaviour among young men in the rural Eastern Cape, South Africa. AIDS. 2006; 20:2107-2114. [PubMed: 17053357]

Dupas, P.; Robinson, J. Savings constraints and microenterprise development: Evidence from a field experiment in Kenya. Cambridge, MA: National Bureau of Economic Research; 2009.

Dworkin SL, Dunbar M, Krishnan S, Hatcher AM, Sawires S. Uncovering tensions and capitalizing on synergies in HIV/AIDS and anti-violence programs. American Journal of Public Health. 2011; 101:995-1003. [PubMed: 21164091]

Dworkin SL, Kambou SD, Sutherland C, Kapoor A. Gendered empowerment and HIV prevention: Programmatic and policy pathways to success in the MENA region. Journal of Acquired Immune Deficiency Syndrome. 2009; 51(Suppl 3):S111-S118.

Englert, B.; Daley, E., editors. Women's rights to land and privatization in Eastern Africa. Oxford, England: James Curry; 2008.

FIDA (Federation of Women Lawyers). Women's land and property rights in Kenya: Promoting gender equality. 2009. Retrieved from: http://www.law.georgetown.edu/clinics/iwhrc/documents/ Land_and_Property_Report.pdf

Garikipati S. The impact of lending to women on household vulnerability and women's empowerment: Evidence from India. World Development. 2008; 36:2620-2642.

Glick, P.; Fiske, S. Gender, power dynamics, and social interaction. In: Ferree, MM.; Lorber, J., editors. Revisioning gender. Newbury Park, CA: Sage; 1999. p. 365-398.

Goetz AM, Sen Gupta R. Who takes the credit? Gender, power, and control over loan use in rural credit programs in Bangladesh. World Development. 1996; 24:45-64.

Grabe S. Promoting gender equality: The role of ideology, power, and control in the link between land ownership and violence in Nicaragua. Analyses of Social Issues and Public Policy. 2010; 10:146170.

Gupta GR. Gender, sexuality and HIV/AIDS: The what, the why and the how. SIECUS Report. 2001; 29:6-12.

Gupta GR, Parkhurst JO, Ogden JA, Aggleton P, Mahal A. Structural approaches to HIV prevention. Lancet. 2008; 372:764-775. [PubMed: 18687460]

Hashemi SM, Schuler SR. Rural credit programs and women's empowerment in Bangladesh. World Development. 1996; 244:635-653.

Hatcher AM, Turan JM, Leslie HH, Kanya LW, Kwena Z, Johnson MO, et al. Predictors of linkage to care following community-based HIV counseling and testing in rural Kenya. AIDS and Behavior. 2012; 16:1295-1307. [PubMed: 22020756]

Henrysson E, Joireman SF. On the edge of the law: Women's property rights and dispute resolution in Kisii, Kenya. Law \& Society Review. 2009; 43:39-60.

Huairou Commission. Turning good practices into institutional mechanisms: Investing in grassroots women's leadership. 2009. Retrieved from: http://www.huairou.org/campaigns/land/wlla.html

ICRW. Women's property rights, HIV and AIDS, and domestic violence. 2007a. Retrieved from: http://www.icrw.org/publications/womens-property-rights-hiv-and-aids-and-domestic-violence

ICRW. Women's property rights as an AIDS response: Lessons from community interventions in Africa. 2007b. Retrieved from http://www.icrw.org/files/publications/Womens-Property-Rightsas-an-AIDS-Response-Lessons-from-Community-Interventions-in-Africa.pdf

International Center for Research on Women (ICRW). To have and to hold: Women's property and inheritance rights in the context of HIV/AIDS in Sub-Saharan Africa. 2004. Retrieved from: http:// www.icrw.org/publications/have-and-hold-womens-property-and-inheritance-rights-contexthivaids-sub-saharan-africa

Izumi K. Gender-based violence and property grabbing in Africa: Adenial of women's liberty and security. Gender\& Development. 2007; 15:11-23.

Jenkins SR. Introduction to the special issue: Defining gender, relationships, and power. Sex Roles. 2000; 42:467-493. 
Jewkes RK, Levin JB, Penn-Kekana LA. Gender inequalities, intimate partner violence and HIV preventive practices: Findings of a South African cross-sectional study. Social Science and Medicine. 2003; 56:125-134. [PubMed: 12435556]

Jewkes, R.; Sikweyiya, Y.; Morrell, R.; Dunkle, K. Understanding men's health and use of violence: Interface of rape and HIV in South Africa. Pretoria, South Africa: Medical Research Council; 2009.

Kabeer N. Conflicts over credit: Re-evaluating the empowerment potential of loans to women in rural bangladesh. World Development. 2001; 29:63-84.

Kalichman SC, Simbayi LC, Kaufman M, Cain D, Cherry C, Jooste S, Mathiti V. Gender attitudes, sexual violence, and HIV/AIDS risks among men and women in Cape Town, South Africa. Journal of Sex Research. 2005; 42:299-305. [PubMed: 19827234]

Kenya Ministry of Health. Kenya AIDS indicator survey 2007: Preliminary report. Nairobi, Kenya: National AIDS and STI Control Program; 2008.

Kes, A.; Jacobs, K.; Nami, S. Gender differences in asset rights in central Uganda. 2011. Retrieved from http://www.icrw.org/files/publications/Gender-Land-and-Asset-Survey-Uganda.pdf

Kilewo C, Massawe A, Lyamuya E, Semali I, Kalokola F, Urassa E, Biberfeld G. HIV counseling and testing of pregnant women in sub-Saharan Africa: Experiences from a study on prevention of mother-to-child HIV-1 transmission in Dar es Salaam, Tanzania. Journal of Acquired Immune Deficiency Syndrome. 2001; 28:458-462.

Kim J, Watts CH. Gaining a foothold: Tackling poverty, gender inequality, and HIV in Africa. British Medical Journal. 2005; 331:769-772. [PubMed: 16195298]

Kim JC, Watts CH, Hargreaves JR, Ndhlovu LX, Phetla G, Morison LA, Pronyk P. Understanding the impact of a microfinance-based intervention on women's empowerment and the reduction of intimate partner violence in South Africa. American Journal of Public Health. 2007; 97:17941802. [PubMed: 17761566]

Lofland, J.; Lofland, JH. Analyzing social settings: A guide to qualitative observation and analysis. Detroit, MI: Wadsworth; 1995.

Mayoux L. Women's empowerment and micro-finance programmes: Strategies for increasing impact. Development in Practice. 1998; 8:235-241. [PubMed: 12293706]

Medley AC, Garcia-Moreno S, Maman S. Rates, barriers, and outcomes of HIV serostatus disclosure among women in developing countries: Implications for prevention of mother-to-child transmission programmes. Bulletin of the World Health Organization. 2004; 82:299-307. [PubMed: 15259260]

Mendenhall E, Muzizi L, Stephenson R, Chomba E, Ahmed Y, Haworth A, Allen S. Property grabbing and will writing in Lusaka, Zambia: An examination of wills of HIV-infected cohabiting couples. AIDS Care. 2007; 19:369-374. [PubMed: 17453571]

Mojola SA. Fishing in dangerous waters: Ecology, gender and economy in HIV risk. Social Science and Medicine. 2011; 72:149-156. [PubMed: 21146910]

Moore A, Kalanzi DN, Amey FK. To disclose or not to disclose?: Lower class parents living with HIV/AIDS in Lome, Togo. International Journal of Sociology and Social Policy. 2008; 28:351364.

Morse, JM. Designing funded qualitative research. In: Denzin, N.; Lincoln, Y., editors. Handbook of qualitative research. Thousand Oaks, CA: Sage Publications; 1994. p. 220-235.

Palmer, R. Foreword. In: Englert, EDE., editor. Women's rights to land \& privatization in Eastern Africa. Oxford, UK: James Currey; 2008. p. i-iv.

Panda P, Agarwal B. Marital violence, human development, and women's property status in India. World Development. 2005; 33:823-850.

Pandey S. Rising property ownership among women in Kathmandu, Nepal: An exploration of causes and consequences. International Journal of Social Welfare. 2010; 3:281-291.

Parker R, Easton D, Klein C. Structural barriers and facilitators in HIV prevention: A review of international research. AIDS. 2000; 14:S22-S32. [PubMed: 10981471]

Pena N, Maiques M, Castillo GE. Using rights-based and gender-analysis arguments for land rights for women: Some initial reflections from Nicaragua. Gender \& Development. 2008; 16:55-71. 
Prina, S. Do simple savings accounts help the poor to save? Evidence from a field experiment in Nepal. Cleveland, OH: Case Western Reserve University; 2011.

Pronyk PM, Hargreaves JR, Kim JC, Morison LA, Phetla G, Watts C, Busza J, Porter JD. Effect of a structural intervention for the prevention of intimate-partner violence and HIV in rural South Africa: A cluster randomised trial. Lancet. 2006; 368:1973-1983. [PubMed: 17141704]

Pronyk PM, Kim JC, Abramsky T, Phetla G, Hargreaves JR, Morison LA, Porter JD. A combined microfinance and training intervention can reduce HIV risk behaviour in young female participants. AIDS. 2008; 22:1659-1665. [PubMed: 18670227]

Pronyk PM, Kim JC, Hargreaves JR, Makhubele MB, Morison LA, Watts CH, Porter JDH. Microfinance and HIV prevention: perspectives and emerging lessons from rural South Africa. Small Enterprise Development. 2005; 16:26-38.

Razavi, S. The gendered impacts of liberalization: Towards ‘embedded liberalism'?. New York: Routledge; 2008.

Republic of Kenya. Rachuonyo district strategic plan for implementation of the national population policy for sustainable development. 2008a.

Republic of Kenya. Kakamega district strategic plan for implementation of the national population policy for sustainable development. 2008b.

Schuler SR, Hashemi SM. Credit programs, women's empowerment, and contraceptive use in rural Bangladesh. Studies in Family Planning. 1994; 25:65-76. [PubMed: 8059447]

Seeley J, Grellier TB, Barnett T. Gender and HIV/AIDS impact mitigation in sub-Saharan Africa: Recognizing the constraints. Journal of the Social Aspects of HIV/AIDS. 2004; 1:87-98. [PubMed: 17601014]

Sherman SG, German D, Cheng Y, Marks M, Bailey-Kloche M. The evaluation of the JEWEL project: An innovative economic enhancement and HIV prevention intervention study targeting drug using women involved in prostitution. AIDS Care. 2006; 18:1-11. [PubMed: 16282070]

Strauss, A.; Corbin, J. Grounded theory methodology. In: Denzin, NK.; Lincoln, YS., editors. Handbook of qualitative research. Thousand Oaks, CA: Sage; 1994. p. 273-285.

Sumartojo E. Structural factors in HIV prevention: concepts, examples, and implications for research. AIDS. 2000; 14:S3-S10. [PubMed: 10981469]

Turan JM, Miller S, Bukusi EA, Sande J, Cohen CR. HIV/AIDS and maternity care in Kenya: How fears of stigma and discrimination affect uptake and provision of labor and delivery services. AIDS Care. 2008; 20:938-945. [PubMed: 18777222]

UNAIDS. Greater action needed to protect women's inheritance and property rights in the face of HIV/AIDS. Geneva: Joint United Nations Program on HIV/AIDS; 2009. Retrieved from http://www.unaids.org/en/KnowledgeCentre/Resources/FeatureStories/archive/ 2009/20090313_Propertyright.asp

UNAIDS. Report on the global AIDS epidemic. Geneva: Joint United Nations Program on HIV/AIDS; 2010.

USAID. Land tenure, property rights, and HIV/AIDS: Approaches for reducing infection and enhancing economic security. 2009. Retrieved from http://www.ardinc.com/upload/photos/ LAND_TENURE_AND_PROPERTY_RIGHTS_AND_HIV.pdf

Walker, C. Land reform in Southern and Eastern Africa: Key issues for strengthening women's access to and rights in land. Rome, Italy: Food and Agricultural Organization (FAO); 2002. Retrieved from http://info.worldbank.org/etools/docs/library/36270/WWalker-Land\%20Reform\%20and $\% 20$ Gender.pdf

Walsh J. Women's property rights violations and HIV/AIDS in Africa. Peace Review. 2005; 17:189_ 195.

Wingood GM, DiClemente RJ. Application of the theory of gender and power to examine HIV-related exposures, risk factors, and effective interventions for women. Health Education \& Behavior. 2000; 27:539-565. [PubMed: 11009126]

Yngstrom I. Women, wives and land rights in Africa: Situating gender beyond the household in the debate over land policy and changing tenure systems. Oxford Development Studies. 2002; 30:2140 . 


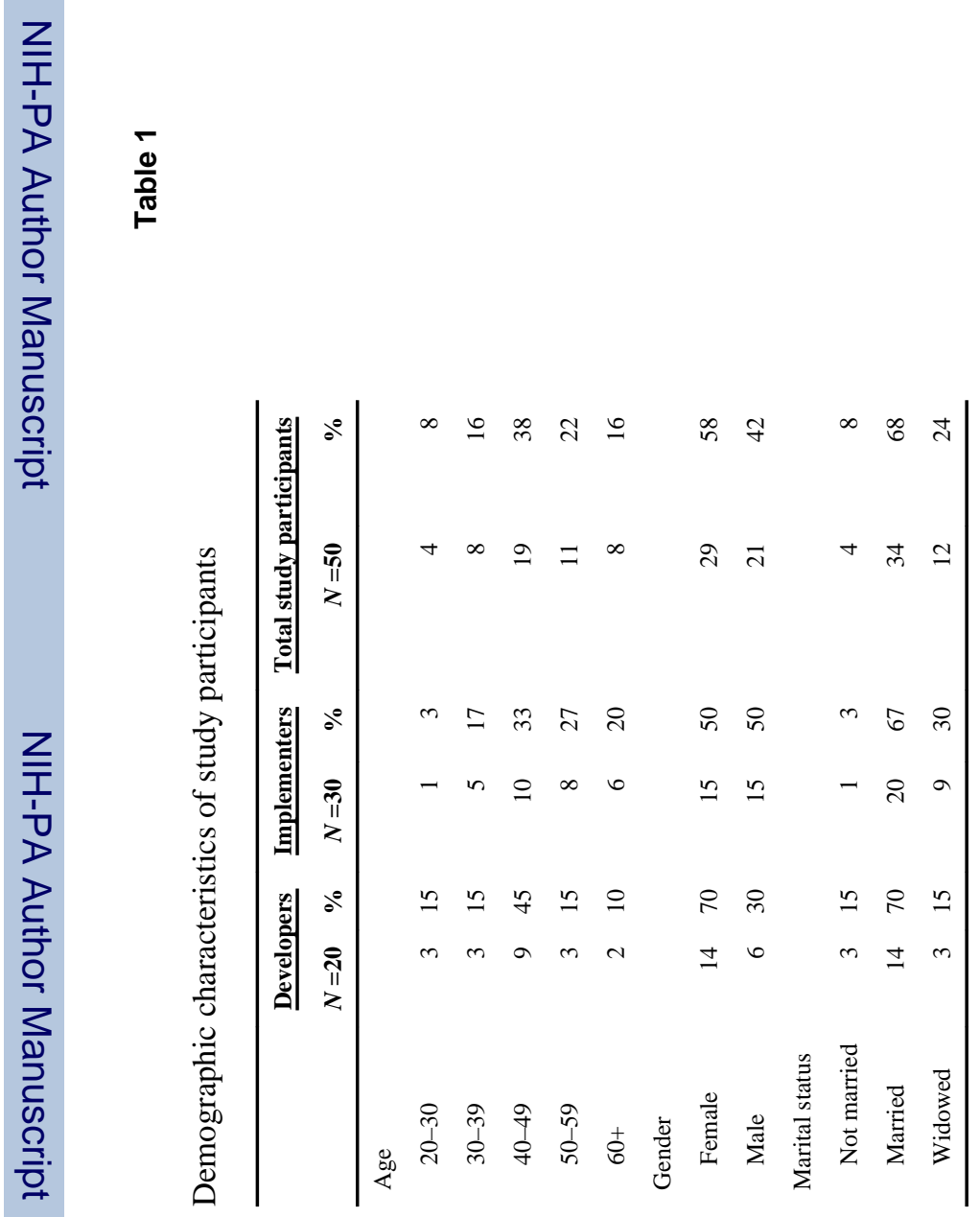

